\section{Forecasting Annual Vegetable Plantings}

\author{
Joseph F. Guenthner'
}

Additional index words. potato, Solanum tuberosum, onion, Allium cepa, acreage response, alternate crops

Summary. Vegetable producers and marketers make business decisions based on supply estimates. The U.S. Dept. of Agriculture provides estimates of planting intentions for field crops but not for most vegetable crops. This study developed models that can be used to forecast vegetable crop plantings. Multiple linear regression analysis was used to determine the factors that influence plantings of potatoes and onions. Field crop planting intentions, industry structure, lagged values of plantings, prices received, price volatility, and the price of sugar beets were found to be significant factors. The models and/ or methods used in this study should be useful to those interested in forecasting vegetable plantings.

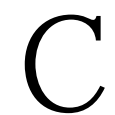
hanges in the supply of vegetable crops can cause relatively large price changes. Accurate forecasts of supplies can enable growers, shippers, processors, and supply firms to make more profitable decisions regarding production, contracts, storage, and timing of sales. The U.S. Dept. of Agriculture (USDA) provides estimates of planted areas for most of the major crops grown in the United States. For the main field crops, USDA not only estimates hectares after planting but also provides an estimate ofplanting intentions before the crop is planted. For mostvegetable crops only the after-planting estimate is done. Exceptions are onions and processor contract intentions for green peas, snap beans, sweet corn, and tomatoes. Those interested in earlier estimates must rely on other sources of information, some of which may be inaccurate.

${ }^{1}$ Extension Horticultural Economist.

Department of A gricultural Economics; University of Idaho; Moscow, ID 83843; phone (208)882-0874; fax (208)885-5759
The objective of this study was to develop models for forecasting vegetable plantings using field crop planting intentions and other relevant data. Due to differences in alternative crops and other factors that affect plantings, the focus was on state rather than national models. The initial models in this study were estimated for Idaho onions ( $15 \%$ of U.S. crop) and Idaho potatoes ( $28 \%$ of U.S. crop). Idaho onions are grown in the Treasure Valley area, the nation's largest fresh-onion production region. Idaho is also the largest potato-producing state.

\section{Methods}

According to Tomek and Robinson (1990), the supply of an agricultural commodity depends on the price of the commodity, input prices, returns of alternative crops, technology, risk, and government programs. Due to the amount of time required to plant, grow, and harvest a crop, Nerlove (1956) verified a time lag between output and prices.

Vegetable planting models have been developed by Hammig (1978), Estes et al. (1982), and Love and Willett (1990) using lagged price relationships. Guenthner and Folwell (1989) built a similar model based on a survey of growers. All these models used lagged prices to handle the alternative crops issue. The model in this study instead uses USDA planting intentions as the alternative crops explanatory variable. This may provide a more reliable variable by capturing actual grower intentions rather than their expected response to prices.

The forecasting equations were estimated by multiple linear regression. The potato model consists of two equations representing the two parts of Idaho for which USDA reports potato plantings: 1) the 10 southwestern counties and 2) all other counties. The southwestern counties are also the primary onion-producing counties in the state.

The potato equations were estimated using USDA-published annual data for the 1978-90 period. While a larger sample size could improve statistical properties, a longer time period was not selected because of changes in industry structure. Earlier data were not used because of the prior collapse of the eastern Idaho sugar beet industry, which changed crop alternatives. The onion equation was estimated from annual data for the 1973-90 period.

\section{Results}

The estimated equations are in Table 1. There are five categories of explanatory variables: 1) hectares planted the previous year; 2) price of the previous crop; 3) price risk; 4) alternate crops prospects; and 5) changes in market structure. All explanatory variables were designed so that forecasts could be made from their current values.

The lagged hectares variable represents "asset fixity." Growing vegetables in the United States requires large investments in specialized equipment, including planters, harvesters, and storage facilities. Once growers. invest in these factors of production they are likely to continue to grow the vegetable crop. The lagged hectares variable can be viewed as a proxy for current investment in vegetable production assets.

Lagged price $(\Varangle / \mathrm{kg})$ also was included because some growers develop their price expectations for the next crop based on the price for the previous crop. The sign of this variable is positive; as prices increase growers respond by planting more hectares.

The third type of variable, price risk, is the difference in price $(\mathrm{e} / \mathrm{kg})$ between the previous 2 years. The negative coefficient in the "other" Idaho potato equation indicates that those growers are risk- averse; increased price volatility causes a reduction in potato plantings. The positive coefficient in the other two equations indicates that southwestern Idaho growers are risk-takers.

One reason for the difference in risk preference is that there are dozens of alternative crops in southwestern Idaho, but relatively few in the rest of the state. Increased price volatility may be seen by southwestern Idaho growers as an opportunity to make money on one of their many crops, but growers in the rest of Idaho may see it as a possibility of losing money on their main crop. A nother reason is that many southwestern Idaho growers contract with potato processors, while eastern Idaho is primarily an open market. With the security of contracts, southwestern Idaho growers can afford to take on more risk for the portion of their crop that is not contracted.

Alternative crop prospects are 
represented by two different types of variables. First, the lagged sugar beet price $(\$ / \mathrm{mg})$ is used because USDA no longer estimates planting intentions for that crop. Second, the planting intentions variable represents the USDA estimate for the relevant field crops that are grown in the area. For the onion equation, this variable is total Idaho planting intentions for wheat, barley, and hay. The selection of these field crops is supported by Greene's (1991) survey of onion growers' alternate crop enterprises. Wheat and barley make up the intentions variable for the other Idaho potato equation; corn, beans, and hay are used for the southwestern Idaho potato equation.

The dummy variables in two of the equations represent changes in the structure of the industry. The variable has a value of 1 after the change and 0 before the change. In the onion equation, the dummy variable represents expansion of onion processing and freshpack facilities in 1985. In the southwestem Idaho potato equation, the dummy variable represents a contraction of the industry due to a potato quality problem. Beginning in 1986, potato processors reduced the amount of hectares contracted in the region because of concerns about sugar ends. Potato plantings dropped from 12,150 hectares in 1985 to 6885 hectares in 1986.

\section{Discussion}

The $\mathbf{R}^{2}$ values in Table 1 indicate that more than $90 \%$ of the variation in hectares is explained by the equations. The accuracy of the onion model can be compared to the USDA intentions reports (Table 2). The comparison is not direct because the USDA estimate is for the Treasure Valley, which indudes southwestern Idaho as well as eastern Oregon-a separate intentions report for Idaho was not done. The root mean square error (RMSE) at the bottom of Table 2 indicates that the forecasting equation was a more accurate predictor than the planting intentions report. Out-of-sample forecasts for 1991 gave errors ranging from $-3.5 \%$ for onions to $4.0 \%$ for potatoes in southwestern Idaho, to $6.4 \%$ for potatoes in the rest of the state.

The forecasting models developed in this study may provide more reliable forecasts than the USDA planting intentions reports; one reason is that growers may change their planting plans after they read the planting intentions reports. In a recent survey (Guenthner and Folwell, 1989), growers rated planting projections as the third most important factor they consider when deciding how much to plant. The models developed in this study avoid the problem of grower response to USDA preplaming estimates.

The models fit the data well, and if grower behavior does not change, they could provide reliable forecasts of hectares planted in the future. Grow-

Table 1. Estimated equations for potato and onion hectares planted in Idaho.

\begin{tabular}{|c|c|c|c|}
\hline \multirow[b]{2}{*}{$\begin{array}{l}\text { Explanatory } \\
\text { variables } \\
\end{array}$} & \multicolumn{3}{|c|}{ Dependent variables (ha planted) ${ }^{z}$} \\
\hline & Onions & $\begin{array}{l}\text { Potatoes, } \\
\text { southwest } \\
(1000 \text { ha) } \\
\end{array}$ & $\begin{array}{c}\begin{array}{c}\text { Potatoes, } \\
\text { other } \\
(1000 \mathrm{ha})\end{array} \\
\end{array}$ \\
\hline Constant & 2260.0 & 31.9 & 54.4 \\
\hline Hectares lagged & $\begin{array}{r}0.17 \\
(1.7)\end{array}$ & $\begin{array}{c}0.90 \\
(4.7)\end{array}$ & $\begin{array}{c}0.66 \\
(4.5)\end{array}$ \\
\hline Price lagged $(\Phi / \mathrm{kg})$ & $\begin{array}{c}5.6 \\
(1.6)\end{array}$ & $\begin{array}{r}0.32 \\
(3.6)\end{array}$ & $\begin{array}{c}3.0 \\
(6.9)\end{array}$ \\
\hline Price risk $(\Phi / \mathrm{kg})^{\mathrm{y}}$ & $\begin{array}{c}5.7 \\
(1.4)\end{array}$ & $\begin{array}{l}0.42 \\
(2.2)\end{array}$ & $\begin{array}{l}-2.2 \\
(2.8)\end{array}$ \\
\hline Sugar beet price & & & \\
\hline lagged $(\$ / m g)$ & $\begin{array}{l}-7.2 \\
(2.3)\end{array}$ & $\begin{array}{c}-0.08 \\
(2.1)\end{array}$ & \\
\hline Planting intentions ${ }^{x}$ (1000 ha) & $\begin{array}{c}-0.44 \\
(1.6)\end{array}$ & $\begin{array}{l}-0.05 \\
(4.7)\end{array}$ & $\begin{array}{c}-0.05 \\
(3.9)\end{array}$ \\
\hline Dummy variablew & $\begin{array}{r}932.0 \\
(9.7)\end{array}$ & $\begin{array}{l}-5.2 \\
(8.3)\end{array}$ & \\
\hline$R^{2}$ & 0.98 & 0.98 & 0.92 \\
\hline
\end{tabular}

ㄱalues in parentheses are t ratios.

'The price risk variable is the absolute difference in price the previous two seasons.

"Planting intentions are for corn, beans, and bay in the onion and southwest potato equations, and for wheat and barley in the otherpotato equation.

"D ummy variables represent expansion of processing facilities in the onion equation and the potato sugar end problem in the southwest potato equation.

Table 2. USDA intentions reports.

\begin{tabular}{|c|c|c|c|c|c|c|}
\hline \multirow[b]{2}{*}{ Year } & \multicolumn{3}{|c|}{ Forecasted, Idaho } & \multicolumn{3}{|c|}{ Intentions, Treasure Valley } \\
\hline & Actual & Predicted & Error & Actual & Predicted & Error \\
\hline 1990 & 3159 & 3071 & -88 & 7290 & 7128 & -162 \\
\hline 1989 & 3078 & 3086 & 8 & 7128 & 7128 & 0 \\
\hline 1988 & 3118 & 3130 & 12 & 7290 & 7087 & -203 \\
\hline 1987 & 3159 & 3151 & -8 & 6925 & 6885 & -40 \\
\hline 1986 & 2875 & 2969 & 94 & 6358 & 6480 & 122 \\
\hline 1985 & 2875 & 2856 & -19 & 6885 & 6075 & -810 \\
\hline 1984 & 1903 & 2078 & 175 & 5670 & 5467 & -203 \\
\hline 1983 & 2025 & 1969 & -56 & 5265 & 5062 & -203 \\
\hline 1982 & 2025 & 1982 & -43 & 5062 & 4860 & -202 \\
\hline 1981 & 2065 & 1990 & -75 & 4698 & $--{ }^{z}$ & --- \\
\hline 1980 & 1863 & 1831 & -32 & 4455 & 4414 & -41 \\
\hline 1979 & 1863 & 1957 & 94 & 4779 & 5508 & 729 \\
\hline 1978 & 2146 & 2050 & -96 & 5103 & 5022 & -81 \\
\hline 1977 & 2187 & 2121 & -66 & 5022 & 4536 & -486 \\
\hline 1976 & 2187 & 2081 & -106 & 4657 & 4455 & -202 \\
\hline 1975 & 1863 & 1858 & -5 & 4131 & 4131 & 0 \\
\hline 1974 & 1863 & 1979 & 116 & 4131 & 4252 & 121 \\
\hline 1973 & 2025 & 2114 & 89 & 4333 & 4009 & -324 \\
\hline \multicolumn{2}{|c|}{ Root mean square error } & & 0.78 & & & 1.43 \\
\hline
\end{tabular}


ers, processors, and university specialists might adopt this framework to forecast vegetable plantings in other states. Analysts should account for alternate crops specific to the area and changes in industry structure. The main limitation of the models is that growers do not always behave according to model expectations.

\section{Literature Cited}

Estes, E., L. Blakeslee, and R.C. Mittle hammer. 1982. Regional and national impacts ofexpanded Pacific Northwest potato production. Western J. Agr. Econ. 7:I.

Greene, C. 1991. Characteristics of onion growers and farms in six major onion states. Vegetables and Specialties Situation and Outlook, U.S. Dept. Agr. ERS, A pril.

Guenther, J.F. and R.. Folwell. 1989. Forecasting potato acreage. Proc. Idaho Potato School, Pocatello, 24-27 Jan.

Hammig, M.D. 1978. Supply response and simulation of supply and demand for the Unites States fresh vegetable industry. PhD Diss., Washington State Univ., Pullman.

Love, J.M . and L.S. Willett. 1990. Modelling the U.S. potato industry. Vegetables and Specialties Situation and Outlook, U.S. Dept. Agr. ERS, March.

N erlove, M . 1956. Estimates of the elasticities of supply of selected agricultural commodities. J. Farm. Econ. 38:496-509.

Tomek, W.G. and K.L. Robinson. 1990. Agricultural product prices. 3rd ed. Cornell Univ. Press, Ithaca, N.Y. 